\title{
Developing Student Growth Through Effective Inclusion Skill Sets in the Rural Black Belt Region of Alabama and Mississippi
}

\author{
Kimberly Grantham Griffith, PhD \\ Kevin Jones, Ed.D. \\ Jodie Winship, PhD \\ Esther Howard, Ed.D. \\ University of West Alabama, USA
}

Doi: 10.19044/ejes.v6no3a2

URL:http://dx.doi.org/10.19044/ejes.v6no3a2

\begin{abstract}
Skill sets have been identified as the abilities needed by an individual to perform a job or task. In this mixed methods study, an online survey was developed to collect data identifying those skill sets and the barriers to effective inclusion in rural schools in the Black Belt region of Alabama and Mississippi. For rural administrators, this becomes a challenging task to provide the supports needed for students with disabilities to be successful and prepared to be college and/or career ready when they graduate. Rural school principals must be cognizant of teacher skill sets needed for both general and special education teachers to be competent team members in the inclusion classroom.

Although 242 randomly selected rural school administrators employed in the Black Belt Region of the twin states area were sent an email requesting participation, there was only a $16 \%$ response rate for the survey. Results of the study indicated that principals felt supports that were needed for successful inclusion were related to professional development, common scheduling and planning, and collaboration. Barriers to inclusion were territorial and shared responsibilities, personality conflicts, and insufficient number of staff and coteaching training. One of the conclusions of this study indicated the need of administrators to be aware of the use of a variety of inclusion strategies that support more than just one inclusion model. The second conclusion indicated a need for the College of Education to revise and include additional training in effective inclusion skill sets both within their educator and instructional leadership preparation programs.
\end{abstract}


Keywords: Inclusion, rural principals, teacher skill sets, disabilities, coteaching.

\section{Introduction}

Research indicates the two primary reasons for student growth and success are based on the ability of the teacher to present content knowledge and develop relationships. School administrators have a critical responsibility in molding the learning environment in their schools (Roberts, Ruppar, \& Olson, 2018). Because of this, the instructional leadership of the school is charged with providing supports to their teachers to help them increase student academic growth and enhance their future success.

Part of student success can be tied to the concept of inclusion. The roots of inclusion began with Public Law 94-142, the Education for All Handicapped Children Act of 1975, and has continued to improve the quality of this educational standard through the Individuals with Disabilities Education Act (IDEA) 1990, 1997, and 2004. The implementation of these statutes and the court's interpretation through case law have indicated an ever changing need to review and prepare teachers, administrators, and support personnel to adequately implement inclusion in their schools.

Originally, inclusion put students with disabilities in non-academic environments through the use of mainstreaming. These lesser restrictive environments with their peers without disabilities transformed into what we currently know as inclusion, a shift to include academic placements with their age or grade level peers. Even though schools tout the use of inclusive practices in their general education classrooms, insignificant data has been collected to review the productiveness of this mandate in student growth and success in rural schools (Goulas, Henry, \& Griffith, 2004).

Educators need to acquire specific skills and abilities to successfully perform their job in the classroom. Skill sets are a list of those abilities needed to perform the job or task. Effective inclusion is based on the use of a variety of those predetermined skills, comprehension of the components of the process, and the implementation of research-based instructional strategies (Hoppey, 2016). Teachers need to be able to apply skill sets that bring a variety of scientifically-based instructional strategies to support all students' learning needs and provide accommodations to increase academic and social skill success (Obiakor, Harris, Mutua, Rotatori, Algozzine, 2012).

In general, it is the how and what that both general and special education teachers bring to the inclusion classroom that provides the effective skill sets for a successful classroom (Scruggs and Mastropieri, 2017). Although Scruggs and Mastropieri, 2017, identified two promising practices of effective inclusion, Practice 1: Effective Collaboration and Practice 2: Explicit Instruction, the findings of this study found parallels between rural 
Black Belt school principals' perceptions and the components of the first practice, Effective Collaboration.

\section{Challenges of Rural School Administrators}

The task of adequately preparing students for success in the classroom and to be college and career ready through inclusion, becomes a greater challenge in rural districts where financial, personnel, and community resources are limited. It is critical that administrators are cognizant of inclusion skill sets needed by both general and special education teachers to support student success. For inclusion to be effective, principals need to know what kinds of internal supports are needed and how to provide them to their teachers (Monsen, Ewing, and Kwoka, 2014).

\section{$\underline{\text { Soio-Economics and Demographics of the Black Belt Region }}$}

The Black Belt region which runs through many of the southern states, stretches across nineteen counties in Alabama and seventeen in Mississippi. This area known for its dark fertile soil, which played a role in the agricultural history of cotton in both states, is one of extreme poverty and small rural communities with a lower economic tax-base, limited or poorly trained workforce and regional resources, and greater numbers of minority students served by educators with limited knowledge of diversity and the literacy of poverty. Because of these circumstances, school leaders struggle to meet the academic needs and provide an adequate success rate for college and career readiness skills of its student population.

\section{Purpose of the Study}

The purpose of the study was to identify school administrators' perceptions of the skills needed for effective inclusion classrooms in the Black Belt area of Alabama and Mississippi. Although there is research on attitudes toward inclusion by teachers and principals, limited focus has been on the perceptions of inclusion in rural schools.

A mixed-methods online research survey consisting of qualitative and quantitative questons was developed by a research team that consisted of a former superintendent/instructional leader and three educator preparation faculty, two of them former special educators and one from the area of early childhood/elementary education. The purpose for selecting an online survey as the data collection method was due to easy access by participants who would only have to make a few clicks on their computers to open the survey, answer the questions and then submit their responses. This also provided immediate collection of the data. The team identified the need for addressing training and effectively preparing individuals to deal with the academic needs of children with disabilities in their classrooms and schools. This critical need 
was one that had surfaced through Internship surveys, information gathered from former College of Education graduates and Black Belt administrator focus groups that work collaboratively with this university to prepare educators. The instrument consisted of two parts. The first section included demographic and Likert scale multiple choice questions which were used to collect qunatitative data. The second section involved open ended questions used to identify patterns and needs through a qualitative data collection method.

\section{Method}

The thirty-five question online survey designed for school administrators was developed using the Qualtrics survey program. The questions included demographics, training and experience related to working with individuals with disabilities, principals' perceptions of inclusion and inclusive practices, knowledge of the six inclusive classroom environments, and special and general education inclusion skill sets.

A total of 257 principals were identified in the Black Belt region of Alabama and Mississippi as potential survey participants. After receiving IRB approval, a request for participation in the study was emailed to those principals. Fifteen of those emails were returned as insufficient addresses leaving a total of 242 email recipients. Two additional reminder emails were sent within a two-week period requesting participation in the survey and a reminder that the study would close at the end of that time period.

\section{Results}

The survey, School Administrators of the Black Belt Region of Alabama and Mississippi Perceptions of Educators' Skills needed for Effective Inclusion Classrooms, was conducted winter of 2017 . Of the 242 invited participants, 41 individuals clicked on the link and opened the survey. Thirtynine of those 41 individuals completed the survey questions. The response rate for participation was $16 \%$. A $10-15 \%$ survey rate for an external survey is considered a good response rate since interviewees have no real ties to the organization conducting the study. Internal surveys involving employees working within the organization would be expected to have a higher response rate.

The greatest number of interviewees that participated in the School Administrators of the Black Belt Region of Alabama and Mississippi Perceptions of Educators' Skills Needed for Effective Inclusion Classrooms, $56.41 \%$, were from Alabama. Only $43.59 \%$ of instructional leaders from Mississippi selected to participate in the study. Even though this rural Alabama university sits close to the Mississippi and Alabama state line and is 
committed to preparing educators for school districts in both states, more principals from Alabama participated in the research study.

This research report reviews several areas related to demographics that include the number of inclusion classrooms in the school, state location, and formal training in areas related to special education. Quantitative question \#12 related to the six types of inclusion/co-teaching classrooms. Qualitative questions \#30 and \#31 identified inclusion classroom supports and barriers.

Quantitative Data

$\underline{\text { Inclusion Classrooms }}$

Data presented in Table 1: Percentage of Inclusion Classes in My School, indicates that the majority of principals that participated in the survey, $25.64 \%$ and $20.51 \%$, only had $0 \%-1 \%$ or $2 \%-5 \%$ of inclusion classrooms in their school. The lowest percentages reported were $5.13 \%$ and $2.56 \%$ with $31 \%-40 \%$ and $41 \%-50 \%$ inclusive type environments indicating small numbers of inclusion classrooms being part of the school's instructional environment.

\begin{tabular}{|l|l|l|l|}
\hline \multicolumn{4}{|c|}{ Table 1: Percentage of Inclusion Classes in My School } \\
\hline$\#$ & Answer & \% & Count \\
\hline 1 & $0 \%-1 \%$ & $25.64 \%$ & 10 \\
\hline 2 & $2 \%-5 \%$ & $20.51 \%$ & 8 \\
\hline 3 & $5 \%-10 \%$ & $10.26 \%$ & 4 \\
\hline 4 & $11 \%-20 \%$ & $10.26 \%$ & 4 \\
\hline 5 & $21 \%-30 \%$ & $12.82 \%$ & 5 \\
\hline 6 & $31 \%-40 \%$ & $5.13 \%$ & 2 \\
\hline 7 & $41 \%-50 \%$ & $2.56 \%$ & 1 \\
\hline 8 & $51 \%+$ & $12.82 \%$ & 39 \\
\hline
\end{tabular}

Special Education and Individuals with Disabilities Training

Question \#11, data reported in Table 2: Types of Formal Training Related to Special Education and Individuals with Disabilities, asked participants to report which types of training they had previously had related to special education and individuals with disabilities. The largest percentages disclosed were in the areas of inclusion, $76.92 \%$ and special education law, $79.49 \%$. The lowest percentage involved training in team building, $48.72 \%$ and $56.41 \%$ in the supervision of teachers working in one of the six inclusion type classrooms. 


\begin{tabular}{|l|l|l|l|}
\hline \multicolumn{4}{|l|}{$\begin{array}{l}\text { Table 2: Types of Formal Training Related to Special Education } \\
\text { and Individuals with Disabilities }\end{array}$} \\
\hline$\#$ & Answer & \% & Count \\
\hline 1 & Inclusion & $76.92 \%$ & 30 \\
\hline 2 & Team Building & $48.72 \%$ & 19 \\
\hline 3 & $\begin{array}{l}\text { Special } \\
\text { Education Law }\end{array}$ & $79.49 \%$ & 31 \\
\hline 4 & $\begin{array}{l}\text { Supporting } \\
\text { Inclusion in the } \\
\text { General } \\
\text { Education } \\
\text { Classroom }\end{array}$ & $58.97 \%$ & 23 \\
\hline 5 & $\begin{array}{l}\text { Co-Planning/ } \\
\text { Collaborative } \\
\text { Planning }\end{array}$ & $58.97 \%$ & 23 \\
\hline 6 & $\begin{array}{l}\text { Supervision of } \\
\text { Teachers } \\
\text { Working in One } \\
\text { of the Inclusion } \\
\text { Models Listed }\end{array}$ & $56.41 \%$ & 22 \\
\hline
\end{tabular}

Types of Inclusion/Co-Teaching Models

Question \#12 asked participants the types of inclusion/co-teaching models most frequently used in their schools. Answers ranged from $7.69 \%$, N/A-No co-teaching in my school, to the largest percentage of $33.33 \%$, one teach - one assist. This data is reported in Table \#3: Models of Inclusion Most Frequently Used in My School.

\begin{tabular}{|c|c|c|c|}
\hline $\begin{array}{l}\text { Table \#3: } \\
\text { School }\end{array}$ & els of Inclusion & Most F & y Used \\
\hline$\#$ & Answer & $\%$ & Count \\
\hline 1 & $\begin{array}{l}\text { N/A - No co- } \\
\text { teaching in my } \\
\text { school }\end{array}$ & $7.69 \%$ & 3 \\
\hline 2 & $\begin{array}{l}\text { One Teach - } \\
\text { One Assist }\end{array}$ & $33.33 \%$ & 13 \\
\hline 3 & $\begin{array}{l}\text { One Teach - } \\
\text { One Observe }\end{array}$ & $7.69 \%$ & 3 \\
\hline 4 & $\begin{array}{l}\text { Station } \\
\text { Teaching }\end{array}$ & $10.26 \%$ & 4 \\
\hline 5 & $\begin{array}{l}\text { Parallel } \\
\text { Teaching }\end{array}$ & $5.13 \%$ & 2 \\
\hline 6 & $\begin{array}{l}\text { Alternative } \\
\text { Teaching }\end{array}$ & $17.95 \%$ & 7 \\
\hline 7 & $\begin{array}{l}\text { Team } \\
\text { Teaching }\end{array}$ & $17.95 \%$ & 7 \\
\hline
\end{tabular}


Qualitative Data

$\underline{\text { Inclusion Supports - Question \#30 }}$

Question \#30 included qualitative information where principals provided short answers on the types of supports given to both general and special education teachers to be successful in the inclusion classroom. Three themes appeared when reviewing the data. Professional development and workshops, common planning and scheduling, and collaboration were mentioned by almost all of those completing the survey.

\section{$\underline{\text { Professional Development }}$}

Professional learning communities, professional development opportunities and workshops were combined to indicate additional training needed by and provided to many of the teachers. One principal noted that both general and special education teachers were provided the same support and exposure to professional development needs, however, teachers are afforded different individual opportunities based on their personal choice for training. Another commented that consultants from content-specific areas provided distinct strategies to support students in the inclusion classroom. General and special education teachers had the opportunity to attend these trainings together. Some respondents noted the importance of training on co-teaching skills and the participation in all professional development activities together.

\section{Common Planning and Scheduling}

Numerous individuals reported daily common planning time and flexible schedules in several of their comments. To provide for effective services for students with disabilities, planning times are the same for the inclusion and homeroom teacher. Several administrators identified that that these times should be used to coordinate support of special needs students. Two individuals mentioned this common planning time should also be used to plan for peer observations.

\section{Collaboration}

Significant comments on collaboration were also noted as part of this question. Scheduling time for collaboration and identifying its significance, contributed to the classroom climate. One principal encouraged the special education teacher to be part of the classroom and participate in all grade level meetings. Another mentioned that this provided an understanding of what they are going through.

\section{Additional Perspectives Provided in the Survey}

One principal added several thoughts that encompassed many of the elements of the role of the special education teacher. This respondent felt that 
a principal should have a fundamental knowledge of the scope of the special educator's role. This role includes teaching, curriculum and lesson planning as well as aligning those plans with college and career-ready standards, specially-designed instruction, content knowledge for the areas where they provide academic support and instruction, facilitating meetings, progress monitoring, managing communications, knowledge of the law and requirements of paperwork, and the constant changes required by the Individuals with Disabilities Education Act (IDEA). With all of this, special education teachers need to have constant contact with general education teachers.

Others included walk through observations and the use of district level specialists to support academic and behavioral needs of challenging students. Three of the individuals surveyed also commented on the use of assistant teachers and paraprofessionals to assist with those students with more significant educational, behavioral and social needs in the inclusion classroom.

\section{Inclusion Barriers - Question \#31}

Data from qualitative question, \#31, "What do you consider to be barriers to inclusion in your school?" is the last question presented in this research report. Being territorial and sharing responsibility, personality conflicts, scheduling problems, insufficient numbers of special education teachers, and inadequate skills and training in co-teaching were common threads seen in the responses of the administrators.

\section{Territorial and Shared Responsibility}

A comment was made that the general education mindset is one of the top barriers to inclusion in their school. Many general education teachers already felt overwhelmed without adding students with unique needs to their general education classroom. Several administrators wrote that general education teachers are territorial people. Many feel that this is their classroom and leave special education teachers out of planning. Another wrote their barrier was getting the regular and special educators to share the responsibility of teaching all students and effectively planning student centered activities that are sensitive to student needs. General education teachers also do not understand the law regarding disciplining students with disabilities, and the development and successful implementation of a behavior management plan.

\section{Personality Conflicts}

It was noted that many times there are personality conflicts between the individuals that are to work together to help students with special learning needs. One principal stated that there needs to be ownership by both teachers 
and the ability of these two people to work as a team for the benefit of all the students in the classroom. Disagreements on classroom management and teacher expectations for students also contributed as barriers to effective inclusion.

\section{$\underline{\text { Scheduling Problems }}$}

Time and scheduling were main barriers for teachers to collaborate. There is a need to incorporate more instructional aides to provide the one to one support. A respondent included that collaboratively we must depend on each other's strengths, knowledge and abilities. Time must be used to build trust between these educators.

\section{Insufficient Inclusion Staff}

There was a consensus among several of the principals that there are not enough inclusion teachers in the schools. It was mentioned how difficult it was for the special education teacher to manage multiple subjects and grade levels of their assigned students they worked with. Many of the inclusion teachers ultimately work with only one of the grade levels, ignoring the needs of the other students.

\section{Training Needs for Co-Teaching}

Several comments were made on the need for training. Teachers need guidance and coaching to become effective collaborators in co-teaching. Several principals indicated the need for instruction for both general and special educators for effective communication between the teachers, parents and other school-related staff. Prior professional development before the first year of teaching and the need for colleges to use a blended approach in their educator preparation programs will give general education teachers more practical special education knowledge. The lack of co-teaching skills and the fear of the unknown regarding inclusion were additional concerns.

\section{Conclusion:}

In the United States, over one-third of schools are located in rural communities (Preston and Barnes, 2017). That is a significant number of educational institutions with unique responsibilities for school administrators to support the academic, social and behavioral growth of its students. One of those areas of critical need in the successful management of student growth is the implementation of effective teacher skill sets for the rural inclusion classroom.

Data collected from an online survey sent to rural school principals in the Black Belt region of Alabama and Mississippi, indicated similar requirements and identified specific skill sets needed by teachers for inclusion 
classrooms. Those needs found in two of the qualitative questions of this study were parallel to the components of Practice I: Effective Inclusion. Research conducted by Scruggs and Mastropieri, 2017, indicated common challenges for successful inclusion were communication, planning time, content mastery, control and turf issues, differences in teaching philosophy, and disagreements in discipline and behavior management. Fowler, Coleman, and Bogdan, 2019, also indicated that there was a problem with planning together with other faculty in their research with $79 \%$ of their participants lacking this value collaborative tool which also correlated with the results of this study.

It was interesting to see how the various responses from these rural school principals compared with those areas already identified as challenges and best practices needed to make inclusion work for all students. Although rural administrators have unique challenges to supporting student success in their schools in Alabama and Mississippi, they have similar perceptions of the supports and barriers that must be overcome to prepare students for their state's college and career-readiness skills and successful future citizens of their communities.

Additional information from the survey provided insight into the needs of administrators to be aware of the use of a variety of inclusion strategies that support more than just the one teach - one assist model. Replication of different approaches involving both educators as co-teachers could be explored and implemented in the same instructional environment.

Data from this study is being used to determine the level of training and support needed to prepare future and current educators in effective skill sets critical for successful inclusion classrooms. The College of Education is using information to redevelop its degree programs to more effectively prepare general and special education teachers to work collaboratively to support student growth in application-based classrooms in partner schools within the Black Belt region. This data is also a future catalyst in the development of training to be used to guide school administrators to improve the achievement of students with disabilities.

\section{References:}

1. Goulas, F. M., Henry, L. J., \& Griffith, K. (2004). Making inclusion work in rural Southeast Texas. Electronic Journal for Inclusive Education, 1 (8).

2. Hoppey, D. (2016). Developing educators for inclusive classrooms through a rural school-university partnership. Rural Special Education Quarterly, 35 (1), 13 - 22.

3. Fowler, S.A., Coleman, M.R.B., \& Bogdan, W. K. (2019). The state of the special education profession survey report. TEACHING Exceptional Children, 52(1), 9-27. 
4. Monsen, J. J., Ewing, D. L. \& Kwoka, M. (2014). Teachers' attitudes towards inclusion, perceived adequacy of support, and classroom learning environment. Learning Environments Research, 17 (1), 113 $-126$.

5. Obiakor, B. E., Harris, M., Mutua, K., Rotatori, A., \& Algozzine, B. (2012).

6. Making inclusion work in general education classrooms. Education and Treatment of Children, 35 (3), 477 - 490.

7. Preston, J. P., \& Barnes, K. (2017). Successful leadership in rural schools: Cultivating collaboration. Rural Educator, 38 (1) 6 - 15.

8. Roberts, C. A., Ruppar, A. L., \& Olson, A. J. (2018). Perceptions matter: Administrators' vision of instruction for students with severe disabilities. Research and Practice for Persons with Severe Disabilities, 43 (1), 3 - 19.

9. Scruggs, T. E., \& Mastropieri, M. A. (2017). Making inclusion work with co-teaching. TEACHING Exceptional Children, 49 (4), 284-293. 